\title{
Patient blood management and the Covid-19 Pandemic: An institutional study
}

\author{
Soumya Hadimani ${ }^{*}$, Subhashish Das, Kalyani R., Azeem mohiyuddin S.M, Prabhakar K
}

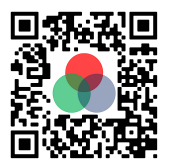

Use your smartphone to scan this QR code and download this article

Sri Devaraj Urs Medical College, India

\section{Correspondence}

Soumya Hadimani, Sri Devaraj Urs Medical College, India

Email: daspathology@gmail.com

History

- Received: Oct 27, 2021

- Accepted: Jan 08, 2022

- Published: Feb 03, 2022

DOI : 10.15419/ajhs.v8i1.498

\section{Check for updates}

\section{Copyright}

( $)$ Biomedpress. This is an openaccess article distributed under the terms of the Creative Commons Attribution 4.0 International license.

\begin{abstract}
Introduction: The COVID-19 pandemic in India is part of the worldwide pandemic of coronavirus disease 2019 (COVID-19). Despite no convincing evidence that this virus can be transfusiontransmitted, the absolute disruption we have seen in everyday life has dramatically reduced the amount of blood donations. Applying the Patient Blood Management (PBM) method is very useful. It is the scientific use of safe and effective medical and surgical techniques designed to prevent anemia and decrease bleeding to improve patient outcomes. PBM conserves a precious community resource, reduces unnecessary hospital and patient care costs, improves patient safety by minimizing exposure to blood, can reduce the risk of hospital-acquired complications and infections, and increases the consumer interest in safety. Efforts to correct anemia in the general population, as well as the implementation of safe blood drive protocols, must be in place to mitigate the risk of viral exposure. This study aimed to assess the indications and requirements of blood and blood products in Covid-19 cases and to develop safe transfusion practices concerning PBM during the Covid-19 pandemic. Methods: This observational study was done in the Blood Bank RLJ Hospital Department of Pathology attached to Sri Devaraj Urs Medical College \& Hospital. The records of all COVID-19 positive patient's including their history, blood and blood component utilization from the medical record section, as well as the blood bank and requisition forms sent to a laboratory for investigation and collected over a duration of 6 months (March 2020 to August 2020). Results: Out of 200 COVID-19 positive cases analyzed, only 70 (35\%) patients received a blood transfusion, in which $64.28 \%$ (45) patients received single unit PRBCs because of severe anemia and pregnancyrelated anemia. Additionally, $25.7 \%$ (18) patients received a platelet transfusion because of underlying comorbidities, and 10\% (7) received FFP. In all COVID-19 positive patients, we observed a raised ESR. A few patients had raised PT and APTT levels. Patients with mild and moderate anemia presented with microcytic hypochromic anemia and normocytic normochromic anemia. We adopted the Cleveland clinic blood management for low hemoglobin to avoid unnecessary blood transfusions. Conclusion: PBM was found to be an important interventional tool to meet the shortage of blood during the COVID-19 pandemic successfully. An evidence-based emergency blood management plan and flexible regulatory policy should be ready to deal with any disaster and to respond quickly in the case of a blood shortage. While pandemics may reduce the blood supply, our study demonstrated that hospitalized COVID-19 patients had a low level of blood usage. Future studies examining the impact of patient factors may help to further elucidate the mechanisms affecting blood utilization in hospitalized COVID-19 populations.
\end{abstract}

Key words: Covid-19 pandemic. Blood transfusion, Patient blood management (PBM)

\section{INTRODUCTION}

The COVID-19 pandemic in India is part of the worldwide pandemic of coronavirus disease 2019 (COVID-19) $^{1,2}$. Despite no convincing evidence that this virus can be transfusion-transmitted, the absolute disruption we have seen in everyday life dramatically has reduced the amount of blood donations ${ }^{3,4}$. The duration of the pandemic is still unknown, and the challenges in terms of blood availability will remain present for an unknown duration. Applying the $\mathrm{Pa}-$ tient Blood Management (PBM) method is very useful. It is the scientific use of safe and effective medical and surgical techniques designed to prevent anemia and decrease bleeding to improve patient outcomes. PBM conserves a precious community resource, reduces unnecessary hospital and patient care costs, improves patient safety by minimizing the exposure to blood, reduces the risk of hospital-acquired complications and infections, and increases the consumer interest in safety. Efforts to correct anemia in the general population, as well as the implementation of safe blood drive protocols, must be in place to mitigate the risk of viral exposure ${ }^{5-7}$. The COVID-19 virus has a serious impact on old age with comorbidities in immunosuppressed and immunodeficiency patients. ${ }^{8}$ In 
this study, we aimed to assess the indications and requirements of blood and blood products in COVID19 cases to develop safe transfusion practices concerning patient blood management (PBM) during the COVID-19 pandemic. Sharing experience and developing an expert consensus based on evolving publications will help transfusion services and hospitals in countries at different stages in the pandemic ${ }^{8-10}$.

\section{METHODS}

This observational study was done in the Blood Bank RLJ Hospital Department of Pathology attached to Sri Devaraj Urs Medical College \& Hospital. The records of all the COVID-19 positive patients including their history, blood and blood components utilization from the medical record section, as well as their blood bank and requisition forms sent to a laboratory for investigation, were collected over a duration of 6 months (March 2020 to August 2020).

\section{RESULTS}

In the present study, we analyzed 200 cases of COVID-19 positive patients confirmed by the RTPCR method. Out of these 200 patients, 130 were male and 70 were female. The average age group of these patients was $>51-75$ yrs (37.91\%) while $31.31 \%$ were from the age group $>26-50$ (Table 1). When their history was analyzed, the majority of patients had previously diagnosed comorbidities which have been listed in Table 2 .

Regarding the complete blood count, ESR, PT, and APPT was done for all patients, of which $22.5 \%$ had severe anemia ( $<7$ gm\%) and needed PRBC transfusion. Additionally, $80 \%$ of patients had neutrophilic leukocytosis and $16.5 \%$ of patients had a normal WBC count. A few cases had leucopenia totaling 2.5\% while $1 \%$ had leukemia. Following on from this, $68.5 \%$ of patients were had a platelet count of more than 100 thousand/cumm, thus requiring no platelet transfusion. Only $9 \%$ of patients presented with severe thrombocytopenia because of underlying comorbidities like alcoholic liver disease and pregnancy cases that required a platelet transfusion. Meanwhile, $50.98 \%$ cases had normocytic normochromic anemia and $29.41 \%$ had microcytic hypochromic anemia. When ESR was analyzed, $45.5 \%$ of patients had raised ESR between $30-60 \mathrm{~mm} / \mathrm{hr}, 13.5 \%>61-100 \mathrm{~mm} / \mathrm{hr}$ and $9 \%$ of patients had $>100 \mathrm{~mm} / \mathrm{hr}$. PT was raised mildly in $31 \%$ at $15-30$ seconds and it was $>30$ seconds in $5 \%$ of patients. APTT was mildly raised in $48 \%$ at $>35-75$ seconds and $8.5 \%$ of patients were at $>$ 75 seconds (Table 3 ).
Out of the 200 cases analyzed, only 70 (35\%) patients received a blood transfusion as shown in Table 4 , in which $21.42 \%$ (15) of patients received single unit PRBCs because of moderate anemia, 31.4\% (22) of patients received 2 units of $\mathrm{PRBC}$ and $11.4 \%$ (08) of patients received 3 units of PRBCs because of the severe degree of anemia and pregnancy-related anemia. Additionally, 25.7\% (18) of patients received a platelet transfusion because of underlying comorbidities, and $10 \%$ (7) received FFP. As such, there was no indication of blood transfusion due to COVID-19.

In the present study, we observed that patients with mild and moderate anemia presented with microcytic hypochromic anemia and normocytic normochromic anemia. We adopted Cleveland clinic blood management for low hemoglobin to avoid unnecessary blood transfusions.

\section{DISCUSSION}

The COVID-19 pandemic has challenged the world by causing numerous issues in which blood supply and demand is included. Blood is a very precious component that cannot be synthesized externally. In the pandemic, situations maintaining the supply and demand became very challenging ${ }^{11}$. The continuous restoration of the blood supply is crucial.

In this study, out of 200 COVID-19 patients with mild, moderate, and severe anemia totaling $67.5 \%, 10$ $\%$, and $22.5 \%$ respectively, the present study showed there to be no significant association between anemia and the severity of the disease. This was similar to the study done by Dawood et al. ${ }^{12}$

The present study showed there to be leukocytosis in $80 \%$ of patients. Leukocytosis is associated with the severity of the disease. Similar results were seen in the studies done by Taj et al. and Dawood et al. ${ }^{12,13}$. Patients with leucopenia totaled $2.5 \%$. However, these patients were only associated with the severe disease. The association of leucopenia with disease severity and the outcome of COVID-19 was also observed in other Asian studies. However, the studied population showed a smaller percentage compared to $63 \%$ from Wuhan and $42 \%$ of patients outside Wuhan.

The present study showed no significant association between platelet count and disease severity, while Liao et al. found a significantly lower platelet count in patients with a critical disease ${ }^{14,15}$. Fan et al. showed there to be mild thrombocytopenia in $20 \%$ of cases in his study ${ }^{16}$.

In our study, we observed raised levels of ESR in $45.5 \%$ of patients $>31-60 \mathrm{~mm} / \mathrm{hr}$, while $13.5 \%$ of patients has $>61-100 \mathrm{~mm} / \mathrm{hr}$, and $9 \%$ of patients had 


Table 1: Age \& Sex distribution of Covid-19 positive
Patients
\begin{tabular}{cccccc}
\hline Age & Male & Female & Percentage & Total \\
$<25$ yrs & 23 & 12 & $17.5 \%$ & 35 \\
$>26-50$ yrs & 42 & 20 & $31 \%$ & 62 \\
$>51-75$ yrs & 55 & 27 & $41 \%$ & 82 \\
$>76$ yrs & 10 & 11 & $10.5 \%$ & 21 \\
Total & 130 & 70 & $100 \%$ & 200 \\
\hline
\end{tabular}

Table 2: Clinical symptoms \& Comorbidities

\begin{tabular}{lcc}
\hline Associated Covid symptoms & Cases & Percentage(\%) \\
Anemia & 35 & 17.5 \\
HTN \& DM & 33 & 16.5 \\
DM & 32 & 16 \\
COPD & 30 & 15 \\
HTN & 28 & 14 \\
CKD & 15 & 7.5 \\
DUB With Covid symptoms & 8 & 4 \\
Pregnancy with Covid symptoms & 6 & 3 \\
Ca Buccal mucosa & 5 & 2.5 \\
Alcoholic disease & 3 & 1.5 \\
Eclampsia with Covid symptoms & 3 & 1.5 \\
Leukemia & 2 & 1 \\
\hline
\end{tabular}

HTN: Hypertension, DM: DiabetesMilleitus, COPD: Chronic Obstructive Pulmonary diseases, CKD: Chronic Kidney Diseases, DUB: Disfunctional Uterine Bleeding, Ca Buccal mucosa: Carcinoma Buccal mucosa

$>101 \mathrm{~mm} / \mathrm{hr}$. This indicates that COVID-19 might activate a change in plasma characteristic and the form of erythrocyte through an unknown mechanism to elevate the ESR. The consistent increasing level of ESR means a poor prognosis for COVID-19 patients. Persistent increasing levels of ESR could damage the joints ${ }^{17}$.

In the present study, we observed that in $31 \%$ of patients, PT was > $16-30$ seconds and 5\% showed > 30 seconds. APTT show elevated levels in $48 \%$ of patients with $>36-75$ seconds and $8.5 \%$ patients showing levels $>75$ Seconds. This study showed there to be an association between APTT and PT with a worsening of the disease. APTT was found to be prolonged in critical cases. Similar findings were observed by Iba et al. and Taj et al. ${ }^{13,18}$. They evaluated that PT and APTT were either deranged or normal in COVID-19 patients. These parameters depend on the extent of coagulopathy and its association with other comorbidities like alcoholic liver dis- ease, pregnancy, hemolytic uremic syndrome, thrombotic thrombocytopenic purpura, antiphospholipid syndrome, disseminated intravascular coagulopathy, and sepsis-induced coagulopathy ${ }^{18}$. Out of the total 200 cases of COVID-19 positive patients, only 70 required blood and blood components, demonstrating that COVID-19 patients required less blood and blood products.

\section{Role of Patient Blood Management in COVID-19}

The nationwide lockdown with stay-at-home orders created an unpredicted decrease in blood supply which led to the risk of shortages. Applying PBM during this period was inevitable. As shown in Table 5, we applied PBM strategies to save blood and blood products.

In Table 4, we observed that the patients requiring single unit PRBCs total $21.42 \%$. This is for treating moderate anemia followed by IV iron sucralose, 
Table 3: Assessment of HB, WBC, Platelet, ESR \& PT, APTT in Covid- 19 Positive Cases

\begin{tabular}{|c|c|c|}
\hline HB (Anemia) & Cases & Percentage (\%) \\
\hline Mild (>10 gm\%) & 135 & 67.5 \\
\hline Moderate (8 - $10 \mathrm{gm} \%)$ & 20 & 10 \\
\hline Severe $(<7$ gm $\%)$ & 45 & 22.5 \\
\hline WBC (Thousands/mm $\mathbf{m m}^{3}$ ) & Cases & Percentage (\%) \\
\hline Normal Counts & 33 & 16.5 \\
\hline Leucocytosis & 160 & 80 \\
\hline Leucopenia & 5 & 2.5 \\
\hline Leukemia & 2 & 1 \\
\hline Platelets (Thousands $/ \mathbf{m m}^{3}$ ) & Cases & Percentage (\%) \\
\hline$>100$ & 137 & 68.5 \\
\hline $101-70$ & 25 & 12.5 \\
\hline $71-30$ & 20 & 10 \\
\hline $31-20$ & 10 & 5 \\
\hline$<20$ & 08 & 4 \\
\hline ESR/ & Cases & Percentage (\%) \\
\hline $0-30$ & 64 & $32 \%$ \\
\hline$>31-60$ & 91 & $45.5 \%$ \\
\hline$>61-100$ & 27 & $13.5 \%$ \\
\hline$>101$ & 18 & $9 \%$ \\
\hline PT & Cases & Percentage (\%) \\
\hline $11-15$ & 128 & 64 \\
\hline$>16-30$ & 62 & 31 \\
\hline$>30$ & 10 & 5 \\
\hline APTT & Cases & Percentage (\%) \\
\hline 26 - 35 Seconds & 87 & 43.5 \\
\hline$>36-75$ & 96 & 48 \\
\hline$>75$ & 17 & 8.5 \\
\hline
\end{tabular}

Table 4: Covid -19 Blood transfusions

\begin{tabular}{ccccccc}
\hline Components & PRBCs single unit & $\begin{array}{c}\text { PRBCs } \\
\text { Double units }\end{array}$ & PRBCs 3 units & Platelets & FFP & Total \\
\hline Cases & 15 & 22 & 08 & 18 & 7 & 70 \\
Percentage(\%) & 21.42 & 31.4 & 11.42 & 25.7 & 10 & 100 \\
\hline
\end{tabular}


Table 5: Adapted from Cleaveland Clinic Blood Management ${ }^{3}$

\begin{tabular}{|c|c|c|}
\hline Hemoglobin & Symptoms & Action taken \\
\hline \multirow[t]{3}{*}{$\mathrm{Hb}:<7 \mathrm{gm}$} & Active bleeding & Transfuse PRBC to achieve $\mathrm{Hb}$ between 8 - 9 gm\% \\
\hline & Symptomatic & Transfuse 1 unit PRBC \& reassess the symptoms \\
\hline & Asymptomatic & $\begin{array}{l}\text { Iron studies \& ferritin levels for all patients \& treat the iron de- } \\
\text { ficiency anemia by IV Iron }\end{array}$ \\
\hline \multirow[t]{3}{*}{$\mathrm{Hb}:>7 \mathrm{gm}$} & Active bleeding & Transfuse PRBC to achieve $\mathrm{Hb}$ between 8 - 9 gm\% \\
\hline & Symptomatic & $\begin{array}{l}\text { Transfuse } 1 \text { unit PRBC \& reassess the symptoms. If symptomatic } \\
\text { then transfuse } 1 \text { more unit of PRBC then Iron studies \& ferritin } \\
\text { levels, treat with IV iron if iron deficiency anemia is present }\end{array}$ \\
\hline & Asymptomatic & $\begin{array}{l}\text { Medical management by assessing the iron, ferritin, Vitamin B12 } \\
\text { levels. IV iron \& IV vitamin B12 if iron or vitamin B12 deficiency } \\
\text { anemia is present }\end{array}$ \\
\hline
\end{tabular}

Table 6: PBM Strategies ${ }^{6}$

\begin{tabular}{|c|c|c|}
\hline & Considerations & Possible actions \\
\hline $\begin{array}{l}\text { Red blood cell } \\
\text { Usage }\end{array}$ & Red blood cell shortages & $\begin{array}{l}\text { Patients with mild anemia should be given oral and IV Iron } \\
\text { sucrose and can reduce the usage of PRBCs. }\end{array}$ \\
\hline Platelet usage & $\begin{array}{l}\text { Platelet shortages for } \\
\text { prophylactic transfusion }\end{array}$ & $\begin{array}{l}\text { Prophylactic usage of platelets should be minimized in pa- } \\
\text { tients with thrombocytopenia } \\
\text { without any bleeding symptoms and careful monitoring of pa- } \\
\text { tients to be done. }\end{array}$ \\
\hline Major bleeding & $\begin{array}{l}\text { Blood shortages for patients } \\
\text { with bleeding }\end{array}$ & $\begin{array}{l}\text { Patients with bleeding should be transfused } 1: 1: 1 \text { for red } \\
\text { blood cells, plasma, and platelets, or } 1: 1 \text { for red blood cells } \\
\text { and plasma if platelets are not available. If there is shortage of } \\
\text { red blood cells consider giving plasma first or blood compo- } \\
\text { nents at ratios of 1:2:1 }\end{array}$ \\
\hline $\begin{array}{l}\text { Alternatives for } \\
\text { Transfusion }\end{array}$ & $\begin{array}{l}\text { At times of severe short- } \\
\text { age alternatives to transfu- } \\
\text { sion can be given. }\end{array}$ & $\begin{array}{l}\text { Use of, Erythropoitein, oral or IV Iron sucrose \& Tranxemic } \\
\text { acid for bleeding. }\end{array}$ \\
\hline
\end{tabular}

iron tablets, etc. Double and triple units of PRBCs were transfused in $31.4 \%$ and $11.42 \%$ respectively with severe anemia followed by IV iron sucrose, oral iron tablet and vitamins supplementation, along with treating the underlying cause of the bleeding.

In the present study, we observed that only $18 \%$ required a platelet transfusion among the COVID-19 patients. This showed there to be no significant association between platelet count with the severity of disease and the direct cause of the COVID-19 disease. Instead, it was due to an underlying cause and comorbidities. In this study, we observed that only $10 \%$ of patients required FFP. Even though the PT and APTT were deranged, the FFP requirement was less, indicating that other parameters like D-Dimer, ferritin, Lactate dehydrogenase, and CRP levels also play an important role in the severity and outcome of the disease. However, we could not investigate these parameters in this study.

When we analyzed the data, the overall transfusion requirements of the COVID-19 patients were very low. However, applying PBM during a pandemic like COVID-19 will help us be ready for unpredictable situations.

On the topic of developing safe transfusion practices concerning patient blood management (PBM) during the COVID-19 pandemic, there is no data on the number of patients who have donated blood presymptomatically, asymptomatically, or after recovery from COVID-19. The risk of transmission of COVID19 through the route of blood transfusion is very low ${ }^{19}$.

The guidelines for transfusion should cover the overall message of decreasing the usage of blood. In combination with various health agencies, blood transfusion services will provide a profit to biobanks throughout 
the course of the COVID-19 pandemic ${ }^{20}$.

In the severe COVID-19 pandemic, a wide range of local alleviating strategies can be utilized in blood paucity (Table 6) ${ }^{21}$. Initially, following the policies based on the national guidance documents for planning in the event of blood shortages will help to plan, execute, and address the blood shortage situations ${ }^{22}$.

\section{CONCLUSIONS}

This study concluded that patients with COVID-19 with a severe to critical form of the disease had increased leukocytes neutrophils and increased ESR, PT, and APTT. We observed that a decrease in hemoglobin and COVID-19 has no significant association. COVID-19 occurs more in patients with underlying comorbidities. It has been proven that COVID-19 patients have deranged hematological and coagulation parameters which can be used for prognosis and the early detection of the disease. This helps us to take appropriate measures to treat patients developing organ failure or shock. PBM is an important interventional tool to combat the shortage of blood during the COVID-19 pandemic successfully. Documented proof for use in the emergency blood management scheme and supple official policy should be ready in case of a blood shortage, and to help deal with any disaster and respond quickly. Pandemics like COVID-19 where there is a lockdown may decrease the blood supply. This study revealed that hospitalized COVID-19 patients have a low blood usage using the PBM method. Future studies are needed to determine the effect of blood utilization in hospitalized COVID-19 populations.

\section{ABBREVIATIONS}

APTT: Activated partial Thromboplastin clotting time, ESR: Erythrocyte sedimentation rate, FFP: Fresh Frozen Plasma, Hb: Hemoglobin, PBM: Patient Blood management, PRBC's: packed Red Blood Cells, PT: Prothrombin Time, RT-PCR: Real-Time Reverse Transcription, WBC: White blood cells

\section{ACKNOWLEDGMENTS}

None.

\section{AUTHOR'S CONTRIBUTIONS}

Soumya. Hadimani: Concept, Literature review, Data analysis, Manuscript editing.

Subhashish Das: Concept, Data analysis, Manuscript editing, review.

Kalyani. R: Data analysis, Literature Review, Manuscript editing.

S. M. Azeem mohiyuddin: Data analysis, Literature Review, Manuscript editing.

Prabhakar. K: Literature Review, Manuscript editing.

\section{FUNDING}

None.

\section{AVAILABILITY OF DATA AND MATERIALS}

Not applicable.

\section{ETHICS APPROVAL AND CONSENT TO PARTICIPATE}

This study was conducted in accordance with the amended Declaration of Helsinki. The institutional review board approved the study, and all participants provided written informed consent.

\section{CONSENT FOR PUBLICATION}

Not applicable.

\section{COMPETING INTERESTS}

The authors declare that they have no competing interests.

\section{REFERENCES}

1. Cai X, Ren M, Chen F, Li L, Lei H, Wang X. Blood transfusion during the COVID-19 outbreak. Blood Transfusion. 2020;18(2):7982. PMID: 32267830.

2. Gehrie EA, Frank SM, Goobie SM, Frank MD, Susan M, Goobie MD. Balancing Supply and Demand for Blood during the COVID-19 Pandemic. Anesthesiology. 2020;133(1):168. PMID: 32550680. Available from: 10.1097/ALN. 0000000000003341 .

3. Tolich D, Auron M, McCoy K, Dargis M, Quraishy N. Blood management during the COVID-19 pandemic; 2020. Available from: $10.3949 /$ ccjm. 87 a.ccc053.

4. Maintaining a safe and adequate blood supply during the pandemic outbreak of coronavirus disease (COVID-19). World Health Organization.

5. Impacts of immunosuppression and immunodeficiency on COVID-19: A systematic review and meta-analysis.

6. Stanworth SJ, New HV, Apelseth TO, Brunskill S, Cardigan $\mathrm{R}$, Doree C. Effects of the COVID-19 pandemic on supply and use of blood for transfusion. The Lancet Haematology. 2020;7(10):e756-64. PMID: 32628911. Available from: 10. 1016/S2352-3026(20)30186- 1.

7. Lee AY, Connors JM, Kreuziger LB. COVID-19 and Coagulopathy: Frequently Asked Questions. Version 3.0. Washington (DC): American Society of Hematology; 2020.

8. Thachil J, Tang N, Gando S, Falanga A, Cattaneo M, Levi M. ISTH interim guidance on recognition and management of coagulopathy in COVID-19. Journal of Thrombosis and Haemostasis. 2020;18(5):1023-6. PMID: 32338827. Available from: $10.1111 /$ jth. 14810 .

9. Shah A, Brunskill SJ, Desborough MJ, Doree C, Trivella M, Stanworth SJ. Transfusion of red blood cells stored for shorter versus longer duration for all conditions. Cochrane Database of Systematic Reviews. 2018;12(12). PMID: 30578732. Available from: 10.1002/14651858.CD010801.pub3.

10. Trivella M, Stanworth SJ, Brunskill S, Dutton P, Altman DG. Can we be certain that storage duration of transfused red blood cells does not affect patient outcomes? BMJ (Clinical Research Ed). 2019;365:I2320. PMID: 31186250. Available from: 10.1136/bmj.12320. 
11. Shander A, Goobie SM, Warner MA, Aapro M, Bisbe E, PerezCalatayud AA, et al. Essential Role of Patient Blood Management in a Pandemic: A Call for Action. Anesthesia and Analgesia. 2020;131(1):74-85. PMID: 32243296. Available from: 10.1213/ANE.0000000000004844.

12. Dawood QM, Al-Hashim ZT, Hijaj BAA, Jaber RZ, Khalaf AA. Study of hematological parameters in patients with coronavirus disease 2019 in Basra. Iraqi J Hematol. 2020;9(2):160-5. Available from: 10.4103/ijh.ijh_49_20.

13. Taj S, Kashif A, Fatima SA, Imran S, Lone A, Ahmed Q. Role of hematological parameters in the stratification of COVID-19 disease severity. Annals of Medicine and Surgery (London). 2021;62:68-72. PMID: 33437468. Available from: 10.1016/j. amsu.2020.12.035.

14. Huang C, Wang Y, Li X, Ren L, Zhao J, Hu Y. Clinical features of patients infected with 2019 novel coronavirus in Wuhan, China. Lancet. 2020;395(10223):497-506. PMID: 31986264 Available from: 10.1016/S0140-6736(20)30183-5.

15. $X u X W, W u X X$, Jiang $X G, X u K J$, Ying $L J, M a C L$. Clinical findings in a group of patients infected with the 2019 novel coronavirus (SARS-Cov-2) outside of Wuhan, China: retrospective case series. BMJ (Clinical Research Ed). 2020;368:m606. PMID: 32075786. Available from: 10.1136/bmj.m606.

16. Fan BE, Chong VC, Chan SS, Lim GH, Lim KG, Tan GB. Hematologic parameters in patients with COVID-19 infection. American Journal of Hematology. 2020;95(6):131-4. PMID:
32129508. Available from: 10.1002/ajh.25774.

17. Pu SL, Zhang XY, Liu DS, Ye BN, Li JQ. Unexplained elevation of erythrocyte sedimentation rate in a patient recovering from COVID-19: A case report. World Journal of Clinica Cases. 2021;9(6):1394-401. PMID: 33644207. Available from: 10.12998/wjcc.v9.i6.1394.

18. TI, Levy JH, Levi M, Thachil J. Coagulopathy in COVID-19. Journal of Thrombosis and Haemostasis. 2020;18:2103-9.

19. Chang L, Yan Y, Wang L. Coronavirus disease 2019: coronaviruses and blood safety. Transfusion Medicine Reviews. 2020;34(2):75-80. PMID: 32107119. Available from: 10.1016/j. tmrv.2020.02.003.

20. Gandhi M, Yokoe DS, Havlir DV. Asymptomatic transmission, the achilles' heel of current strategies to control Covid-19. The New England Journal of Medicine. 2020;382(22):2158-60. PMID: 32329972. Available from: 10.1056/NEJMe2009758.

21. Yazer M, Pagano MB, Cho D, Lin Y. Vox Sanguinis International Forum on transfusion services about response to COVID-19. Vox Sang. 2020;Available from: 10.1111/vox.12943.

22. 32.National Advisory Committee on Blood and Blood Products. Emergency framework for rationing of blood for massively bleeding patients during a red phase of a blood shortage. 2012. https://www. nacblood.ca/resources/shortagesplan/emergency-framework-final. pdf. (accessed March 21 2020).; 2012. 
Ready to submit your manuscript? Choose Biomedpress and benefit from:

- Fast, convenient online submission

- Through peer-review by experienced researchers

- Rapid publication on acceptance

- Free of charge (without publication fees)

Learn more http://www.biomedpress.org/journals/
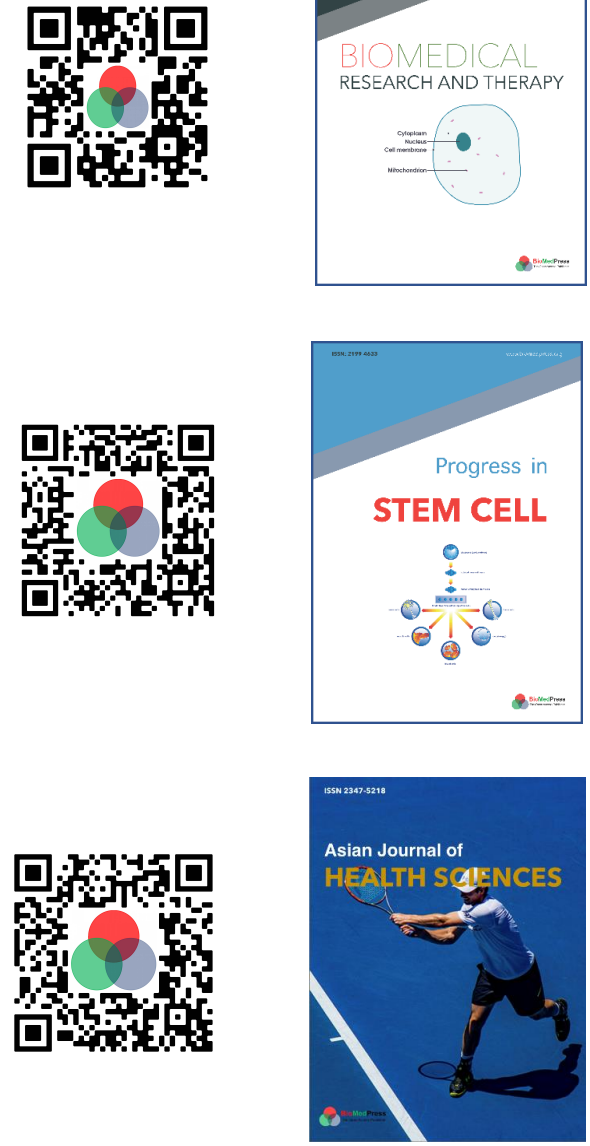

Asian Journal of Health Sciences

ISSN: 2347-5218

Indexed: Google Scholar

Acceptance Rate (2020): 72.89\%

Article Publishing Charge: Free

Submission to first editorial decision: 16.5 days

Biotechnological Research

ISSN: 2395-6763

Indexed: Google Scholar

Acceptance Rate (2020): $67.02 \%$

Article Publishing Charge: Free

Submission to first editorial decision: 28.5 days 